\title{
Travel Web Portal Translation: Region Branding in Context of Globalization
}

\author{
A.A. Gureeva \\ Translation Studies Department \\ Volgograd State University \\ Volgograd, Russia \\ gureeva@volsu.ru
}

\author{
T.S. Sidorovich \\ Translation Studies Department \\ Volgograd State University \\ Volgograd, Russia \\ sidorovich@volsu.ru
}

\author{
A.A. Novozhilova \\ Translation Studies Department \\ Volgograd State University \\ Volgograd, Russia \\ novozilova@volsu.ru
}

\begin{abstract}
The paper provides an analysis of the translation of the text content of the travel web portal of Volgograd and the Volgograd region from Russian into English and German from the perspective of globalization and promotion of the region brand. The paper focuses on the principles of functionally equivalent translation aimed at linguo-cultural and pragmatic adaptation of source tourist texts for the global recipient. It has been demonstrated that translator must have a comprehensive strategy to make a globalized version of the travel web portal, that is: to preserve the optimal amount of general information, to eliminate information irrelevant for the global recipient, and, if appropriate, to add more detailed or explanatory information. Adequate translation of text content of multilingual travel web sites promotes Russian tourism and development of regional branding. The results obtained can be applicable in translation training programmes aimed at translation competence development, working out the ability to use language skills effectively and stimulation of critical pragmatic thinking while creating or translating travel texts addressed to a global recipient. The illustrative text material with the explanation of the chosen translation strategies can be used in practical translation exercises.
\end{abstract}

Key words-translation, globalization, branding, translation methods, adaptation, global recipient.

\section{INTRODUCTION}

Nowadays, the globalization growing in the world is giving a rapid rise in the gradual development of travel industry. Mass character of tourism is greatly determined by a great number of TV-programmes about tourism and travelling in native and foreign cities and countries and ever-growing travel blogosphere, which gives an opportunity to express a tourist's opinion about travel destinations s/he has visited or dream to see and to share personal experience and expectations with other participants of the travel discourse. Tourism is becoming a necessary and sought-after constituent of a modern society. V.A. Mityagina confirms that tourism as a phenomenon of civilization being a mass form of travelling arrangement meets the needs of a person related to the diversification of possibilities and competencies and proves the dynamic character of social and cultural evolution, more spare time, change in value orientation and higher quality of living [1]. E.Yu. Novikova notes that tourism makes an impact on strengthening of interpersonal and intercultural interaction and expands the boundaries of experience and knowledge [2]. Tourism is to be viewed as one of the ways to fulfill the social activity of a person whose wish and need to enrich his / her own cultural and cross-cultural experience is greatly stimulated today by the active attention of the modern mass media to tourism as a fascinating and useful type of rest / entertainment / time spending [3]. Therefore, the travel sphere is not only an important factor of economic development but also a wide field for a person's self-development and fulfillment of individual ambitions. People want to try something new, acquire interesting knowledge and gain a more extensive experience. Traveling gives ample opportunities to bring these ambitions into life. With these tendencies, the popularity of international tourism has grown significantly. S.A. Korolkova and A.P. Naumova note that "more and more people strive to go abroad to visit various places of interest and other countries. The desire to see new places and gain new emotions disseminated by the global mass media favoring the increase in mobility of people in the world" [4]. International tourism is one of the largest and dynamically developing sectors of modern industry which according to V.A. Mityagina has without doubt become "one of the displays of ethnic societies' readiness not only for a dialogue and integration but also for globalization as the travel activity gives opportunities for approval of co-existence of cultures in their individual practices" [5]. The global character of tourist practices and Internet communication determines the search of integration mechanisms to carry out the English- 
language travel web communication in the globalization context [6]. The research conducted by E.Yu. Novikova reveals the fact that globalization, on the one hand, promotes the unification of global communication in whole and cultural tourism in particular and, on the other hand, promotes strengthening of local identity of regions, remembrance and heritage [7]. All these factors result in the necessity to perform intercultural communication in intercultural tourism industry, what, in its turn, as N.V. Filatova suggests, "has become a motive to create advertising and information and reference texts assisting this activity" and "could not fail to attract the attention of scholars and experts in advertising" [8].

A positive image of a foreign city / region and implementation of successful marketing strategies to make this city / region attractive for potential tourists depend on efficient communication within intercultural travel discourse. Travel discourse has a multiple character and performs various functions. It suggests multi-sided research paradigms with a diverse genre peculiarity considering the role played by tourism in the modern society. Different tourism aspects are presented in numerous papers by modern authors. The tourism language analysis is presented in G. Dann's papers [9]. Language as a part of tourist discourse is analyzed in the works conducted by M. Rázusová [10]. The peculiarities of cultural tourism are shown in the papers of E. Bruner [11]. T. Edensor explains the concept of tourist activity as a performance and studies tourist space and practice [12]. History and culture, traditions and cuisine, landscape and natural resources are under scholars' attention. The interest focus of linguists conducting their research of travel discourse has recently started shifting to the analyses of image texts and texts aimed at territorial (place) branding because the proper linguistic assistance of branding is an important component promoting positive character of regions and attracting more tourists into these regions. The scholars note that creation of branding texts in the tourism sector is a complicated task; taking into account the importance of such texts, the scholars point out the following components in the marketing pragmatics:

- attraction of the tourist flow and increase in the revenues of the treasury of a city / region;

- attraction of regional and foreign investors and increase in the inflow of investments;

- increasing influence of the city in the country and abroad;

- establishing partner contacts with private companies / private entities / other cities, etc. [13].

T.Yu. Makhortova argues that a marketing approach to branding being, though, a dominating one, cannot be efficient without linguistic research methods, because the verbal component plays a key role in creation a tourist-attractive image of a country / region / city [14].

As A. Jansson writes "technologies for information gathering, storing and dissemination are involved throughout most tourist trips. They influence perceptions of place, distance, sociality, authenticity, and other pre-understandings that frame tourism". A. Jansson argues that "in tourism, as in many other areas of society, spaces and places are constituted in accordance with the communication they are supposed to enable" [15]. Travel web resources, undoubtedly, can be considered as the most convenient information medium during planning and organization of a tourist trip to any city, especially a foreign one. The rise of interest to a region and increase in the tourist flow, and consequently, additional investment into the travel sector depend directly on how a city is represented in information tourist web resources, and which sights of tourist importance are offered to a potential tourist [3]. Travel portals are information sources which are the most popular among tourists planning their travelling to a certain region. Such portals are located in the Internet and information content and accessibility is their main advantage. A travel web portal of a city creates a special social and cultural space and combines the features and elements of different institutional discourses: media, virtual, administrative, travel, marketing, cultural, etc. That is, it is a powerful tool attracting a wide range of potential consumers and forming an image of a globally oriented city, so-called "glocal" city and region (place) branding in whole [7].

The sphere of place branding engages many practitioners all over the world who are tasked with improving the images of countries, cities, and regions for different kinds of audiences such as tourists, citizens, investors, governments, and the media.

Place image is derived from a location's geography, history, art, music, famous citizens, and other features [16]. Basically, today it seems that governments (countries), municipalities (cities), and councils (regions) everywhere are racing to attain a competitive edge over their competitors [17]. If in the past, a country's, city's, or region's main assets were the products created in its environs, nowadays the assets are country, city, or region itself. Accordingly, governments, municipalities, and regional councils invest great effort in creating a real, competitive advantage over other countries, cities, and regions [18], promoting their superiority in terms of tourism and location [19].

In addition to countries branding themselves, cities and regions all over the globe have also opted to undertake the process. Cities such as Glasgow [20], Manchester [21], London [22,23], Denver [24], Beijing [25], Amsterdam [26], Montreal [27] and many more have already completed the design of their new look and successfully reinforced their positive image in the minds of millions of foreign tourists.

While in the past, the process characterized only developed countries, today, many emerging as well as developing countries allocate significant budgets in order to create more positive and attractive images [17].

Despite the surge in interests in the academic research onsite, branding still remains complicated and somewhat confused construct [28]. The purpose of this paper is to suggest a translation strategy of the travel web portal so as to provide translators with the most correct and applicable region branding strategy. This approach is based on the idea that translation of a travel web portal should be done from the perspective of visitors and tourists, i.e. from the perspective of the "outsiders' culture" or the global recipient.

\section{Methodology}

A travel web portal is one of the important elements of promoting travel potential of a region and a means of creating culturally important social and communicative contexts accumulating from short to detailed and clear information about the most interesting attractions [29]. In addition to rising attention to the attractions of a region among the native population as one of the ways to fulfill the tasks of branding, a quite important and necessary step in a branding programme is to create and promote a tourist attractive image of a region for foreign tourists. In this context, a branding programme needs 
various advertising informative products providing awareness about the most significant travel destinations of a region abroad, and therefore, an active assistance and participation of linguists and translators engaged in the creation of travel texts. A lot of travel web portals have a multilingual version to attract a bigger number of potential foreign tourists. Therefore, the analysis of quality of translation of image texts in the tourism sphere and revealing efficient translation technologies is a priority task of modern linguists aimed at creation of a favorable image of a region.

In this context, it is necessary to analyze the principles of creating a globalized version of a travel web portal addressed to a recipient speaking foreign language. In this paper, the globalization of a content of a web portal is considered on the basis of the texts presented in the travel web portal of Volgograd and the Volgograd region translated from Russian into English and German. The presented multilingual web portal of Volgograd and the Volgograd region "The Volgograd region - territory for travel" (http://volga-land.volsu.ru) is the practical result of the research project "Regional tourism as a factor of discourse and translation technology formation: nominative and communicative-pragmatic conventions of text as a branding tool" conducted within the framework of the regional contest "The Volga Lands in the Culture and History of Russia".

During the creation process of a globalized travel hypertext, not only the pragmatic features influencing the translation process should be considered, but the translation of the texts must also be done in accordance with the principle of transferring "the optimal level of a text completeness" which is defined by E.V. Beloglazova as semantics fair for unambiguous revealing of cognitive models which lay as the basis for the proper interpretation of a text" [30].

The problem to save the adequate volume of the information to fulfill the communicative goals of the participants, despite linguo-cultural and individual differences of the addressees, can be solved by using micro rules, in particular, elimination and generalization allowing revealing the global sense of an episode from the meaning of its sentences [31]. Omission assumes the deletion of propositions which are irrelevant for the global meaning of a text; generalization assumes consolidation of a range of propositions.

Translation of the texts presented in the travel web portal from Russian into English and German assumes significant differences on the extra- and intra-textual levels to achieve the maximum conformity with the expectations of potential recipients. It means that the affinity to the source text can become a tragic mistake during the translation process. Thus, to achieve the functional and pragmatic adequacy it is more important to save the text esthetics from the perspective of the target culture but not the source text.

\section{RESULTS}

Now, let us analyze the examples of globalization of the text content of the tourist web portal of Volgograd and the Volgograd region in accordance with the above-mentioned principles.

\begin{tabular}{|c|c|}
\hline Source text & Translation into English \\
\hline В нескольких десятках & Small bitter salty lake Bulukhta is \\
километрах к западу от озера & situated in Pallasovsky district of \\
Эльтон располагается & the Volgograd region between the \\
небольшое горько-соленое озеро & Volga river and lake Elton. \\
Булухта, что с калмыцкого & \\
языка можноо перевести как & \\
«родниковое». & \\
\hline
\end{tabular}

The location of lake Bulukhta is the key information of the passage. However, its location is described in relation to the other, supposedly known to the Russian recipient, geographic object - lake Elton (literally translated: a few tens of kilometers west of lake Elton). Such description seems to be irrelevant for the global recipient. Thus, the reduction of the description of the lake's location is quite reasonable. The information omitted in the translation is compensated by the description of the lake's location in relation to a "larger" geographic object in Pallasovsky district of the Volgograd region. The information about the etymology of the lake's name is also eliminated as it is not very informative for the global recipient (literally translated: which can be translated from Kalmyk as spring).

\begin{tabular}{|c|c|}
\hline Source text & Translation into English \\
\hline $\begin{array}{c}\text { Гости празднества имеют } \\
\text { возможность погрузиться в } \\
\text { водоворот событий } \\
\text { противоречивого и жестокого } \\
\text { столетия, увидеть Ивана } \\
\text { Грозного, Лжседмитрия II, } \\
\text { государевых стрельцов, вольньх } \\
\text { казаков и европейских } \\
\text { наемников. }\end{array}$ & $\begin{array}{l}\text { Guests of the festival have an } \\
\text { opportunity to plunge into the } \\
\text { atmosphere of the } 16^{\text {th }} \text { century, a } \\
\text { controversial and cruel period of } \\
\text { Russia's history, and meet famous } \\
\text { historical personalities. }\end{array}$ \\
\hline
\end{tabular}

The passage above narrates about the "Kazachya Zastava" International Festival of Military Historical Reconstruction in the Danilovsky district of the Volgograd region. The description of the historical period reconstructed during the festival is aimed at "insiders" and may result in cognitive dissonance for the "outsiders" (literally translated: contradictory and cruel century). Thus, it seems quite obvious to add the $16^{\text {th }}$ century in the translation along with the description of the century. Besides, the passage has information about historical personalities also unknown for the global recipient (literally translated: Ivan the Terrible, False Dmitry II, Monarch's streltsy, free Cossacks, and European mercenaries) which is generalized to famous historical personalities in the translation. Thus, the translator uses cultural and pragmatic adaptation of the key information and eliminates irrelevant information.

\begin{tabular}{|c|c|}
\hline Source text & Translation into English \\
\hline По всему городу открываются & During the festival, the town is \\
«арбузные обжорки»- & full of watermelon small shops \\
прототипь старинных арбузных & where guests can try watermelons \\
лавок, где можно «съесть & and take part in watermelon speed \\
арбузов от пуза», столько, & eating. \\
сколько влезет, но на скорость- & \\
кто больше! & \\
\hline
\end{tabular}

The passage is full of cultural and historical information. The text of translation has diminished in size as compared to the original text due to the cultural adaptation of the key information and elimination of the irrelevant information which is redundant from the point of view of the "outsiders' culture". Though idiom (Eat a bellyful) has been omitted in the translation as well as the details of the process of eating watermelons (literally translated: to eat rapidly - who eats the most), the translated English text has pragmatic advantage. 


\begin{tabular}{|c|c|}
\hline Sourсе teхt & Translation into English \\
\hline В супермаркете Бабы-Яги & In the Park Museum of Russian \\
можно увидеть волшебное & Fairytale, you can see famous \\
зеркальце, отвечающее на все & fairytale characters and a number \\
вопросы с помощью интернета, & of magic attributes. \\
сапоги-скороходы с & \\
противоугонным устройством, & \\
ковёр-самолёт, протёртый & \\
стариком Хоттабычем, & \\
скатерть-самобранку, иапку- & \\
невидимку, гусли-самогуды, & \\
сапоги-скороходы и много других & \\
сказочных атрибутов. & \\
\hline
\end{tabular}

The translation of the passage is much more compressed as compared to the original as the translator uses generalization famous fairytale characters and magic attributes instead of enumerating all the objects - seven-league boots with antithief device; magic carpet frazzled by old man Khottabych; magic tablecloth, cap of invisibility, Russian gusli, etc. Such cultural and pragmatic adaptation is quite applicable as most of the magic heroes and attributes are typical only of Russian fairytales, and despite the fact that some of them can exist in the "outsider' culture", they can differ in some characteristics. That is why the translation can fail to transfer all the flavor of Russian fairytales. The method of generalization is also used while translating the beginning of the passage $B$ супермаркете Бабы-Яги (literally translated: In Baba Yaga's supermarket). Instead, the translator uses the full name of the museum - in the Park Museum of Russian Fairytale.

It should be noted that in all above mentioned examples, the translated text has diminished in size as compared to the original due to the cultural adaptation of the key information and elimination of the irrelevant or redundant information from the perspective of the "outsiders' culture".

When analyzing the text content of the travel web portal translated into German, similar transformations of the original have been discovered.

\begin{tabular}{|c|c|}
\hline Source text & Translation into German \\
\hline $\begin{array}{c}\text { Считается, что Волгоград } \\
\text { был основан в } 1589 \text { году. Тогда } \\
\text { он носил другое название - } \\
\text { Царицын. Изначально } \\
\text { Царицын зарождался как } \\
\text { крепость для обороны южных } \\
\text { грании русских земель. Первое } \\
\text { каменное сооружение возникло } \\
\text { в } 1664 \text { году. Много раз } \\
\text { крепость подвергалась } \\
\text { нападениям со стороньл } \\
\text { взбунтовавшихся крестьян. В } \\
\text { 16о8 году в городе была } \\
\text { заложена первая каменная } \\
\text { иерковь - Иоанно- } \\
\text { Предтеченская, которая была } \\
\text { разрушена в конце ЗО-х годов } \\
20 \text { века и восстановлена в 90-х } \\
\text { годах того же века на } \\
\text { прежнем месте. }\end{array}$ & $\begin{array}{c}\text { Die geographische Lage des } \\
\text { heutigen Wolgograd an der } \\
\text { Landenge zwischen Wolga und } \\
\text { Don ist so günstig, dass schon im } \\
\text { Altertum eine wichtige } \\
\text { Handelsroute durch diese Gegend } \\
\text { führte. } 1589 \text { wurde an der Stelle, } \\
\text { wo heute Wolgograd liegt, die } \\
\text { Festung Zarizyn gegründet. Sie } \\
\text { sollte die südlichen Grenzen } \\
\text { Russlands schützen. Die Festung } \\
\text { wurde mehrfach von } \\
\text { aufständischen Bauern belagert. } \\
\text { 1608 wurde als erste Kirche in } \\
\text { der Stadt die Kirche des Hl. } \\
\text { Johannes des Täufers gegründet. } \\
\text { Ende der } 1930 \text { er Jahre wurde sie } \\
\text { zerstört und in den } 1990 \text { er Jahren } \\
\text { an der früheren Stelle } \\
\text { wiederaufgebaut. }\end{array}$ \\
\hline
\end{tabular}

When translating the passage above the translator uses two different strategies. On the one hand, the translator adds the information missing in the original when translating the history of Tsaritsyn. Thus, he adds some details about geographical location of modern Volgograd, which is situated between two rivers - the Volga and the Don (Die geographische Lage des heutigen Wolgograd an der Landenge zwischen Wolga und Don). And then the translator gives a short comment about important trade routes passed through the territory of the region in ancient times (schon im Altertum eine wichtige Handelsroute durch diese Gegend führte). Therefore, it appears that translation methods of adding and conretization help the translator to guide the foreigner on the territory of Russia. On the other hand, the translator uses omission of the sentence Первое каменное сооружение возникло в 1664 году (literally translated: First stone building was made in 1664). The fact that the first church was also made of stone has been also eliminated in the translation. Both methods used by the translator illustrate cultural and pragmatic adaptation of the translated text which provides easy and adequate perception of the information by foreign tourists.

Below let us consider an example of the translation of the tourist text from Russian into German which illustrates the translation's intention to create a more globalized version as compared to the original.

\begin{tabular}{|c|c|}
\hline Source text & Translation into German \\
\hline $\begin{array}{c}\text { Население Волгограда и } \\
\text { Волгоградской области } \\
\text { многонационально. Здесь } \\
\text { прожсивет более } 120 \\
\text { национальностей: русские, } \\
\text { казахи, украинцы, татары, } \\
\text { армяне, азербайджанцы, казаки, } \\
\text { немцы, иыгане и др. То, что на } \\
\text { территории Волгограда и } \\
\text { Волгоградской области } \\
\text { уникальным образом } \\
\text { сосредоточень различнье } \\
\text { религии, национальности и } \\
\text { культуры является несомненньм } \\
\text { достоинством края. }\end{array}$ & $\begin{array}{l}\text { Im Wolgograder Gebiet leben } \\
\text { mehr als } 120 \text { Nationalitäten } \\
\text { friedlich zusammen: Russen, } \\
\text { Kasachen, Ukrainer, Tataren, } \\
\text { Armenier, Aserbaidschaner, } \\
\text { Kosaken, Deutsche, Roma, Sinti u. } \\
\text { a. Deshalb gibt es neben den } \\
\text { russisch-orthodoxen Kirchen auch } \\
\text { viele Gotteshäuser anderer } \\
\text { Konfessionen. }\end{array}$ \\
\hline
\end{tabular}

The information translated into German is compressed as compared to the original. The translation does not have information about the concentration of various religions, nationalities and cultures as an advantage of the region, but there is information about churches of other confessions among Orthodox churches. Such translation is adequate as foreign tourists are usually interested in visiting churches and temples, and the information about multiconfessional character of the region is less relevant. The translator also uses the method of concretization when translating nationalities of the people living in the Volgograd region and adds information about the western branch of Gypsy - Sinti. This information can be of interest to European tourists as the traditional territory of Sinti's residence is Western Europe including German-speaking countries - Germany, Austria, Switzerland.

\begin{tabular}{|c|c|}
\hline Source text & Translation into German \\
\hline Отправивиись от площади & Vom Platz der Gefallenen \\
Павиих борцов направо по улице & Kämpfer kann man nach rechts \\
Мира в сторону планетария, & gehen, die Uliza Mira mit ihren \\
можно дойти до городской & eleganten cremefarbenen \\
библиотеки имени Горького, & Wohnhäusern und ruhigen \\
полюбоваться тихими улочками & Innenhöfen entlang. Nach einer \\
и старинными домами, & Unterführung sehen wir \\
отдохнуть в сквере. & linkerhand ein modernes, \\
& kastenförmiges weißes Gebäude: \\
& die Gorki-Bibliothek. \\
\hline
\end{tabular}

In this passage, the translator omits one object showing the direction of the route - towards the Planetarium while translating all other objects - from the Fallen Fighters Square to the right along Mira Street, and adds another topographic reference point - underground crossing (Nach einer Unterführung). Such description of the route is more informative from the perspective of a foreign tourist as the Planetarium is not seen from the Fallen Fighters Square. However, additional information about the underground 
crossing will help tourists to move forward in the right direction. Besides, the translation contains a transformed description of the library building: the word combination city library is transformed into a more detailed description - ein modernes, kastenförmiges weißes Gebäude: die GorkiBibliothek, and the translator adds the information about the location of the library relative to a moving tourist - linkerhand (on the left).

The usage of the translation methods described above is adequate as they help to safe semantic content of the original and give better reference points of the route for a foreign tourist.

\section{CONCLUSION}

The examples analyzed illustrate the fact that translators of the travel web portal both from English and German seek to save key information, to eliminate redundant or irrelevant information, and, if appropriate, to add more detailed or explanatory information aimed at foreign tourists.

Thus, when translating the text content of a travel web portal aimed at the global recipient, the translator should use translation methods compliant with discourse strategies and make cultural and pragmatic adaptation of the source text. Without doubt, adequate translation of text content of travel multilingual web sites promote Russian tourism and development of regional branding. Good knowledge of communicative and pragmatic conventions of creation of branding texts, explicating a city as a travel territory, understanding the logics in usage of theoretical linguistic means and practical application to accomplish the tasks and functions of travel branding texts, is one of the key components in applying an optimal technology in translating texts from Russian into English and German.

\section{Acknowledgment}

We would like to acknowledge the director of the Institute of Philology and Intercultural Communication, professor N.L. Schamne and the head of Translation Studies Department, professor V.A. Mityagina for the opportunity to conduct the research and publish its results.

The reported study has been funded by the Russian Foundation for Basic Research (RFBR) and the Government of the Volgograd region. Research project No 17-14-34001 "Regional tourism as a factor of discourse and translation technology formation: nominative and communicativepragmatic conventions of text as a branding tool" (Regional contest "The Volga Lands in the Culture and History of Russia”).

\section{References}

[1] V.A. Mityagina, "The logistics of multilingual tourist discourse: intercultural discourse in the context of globalization," Linguistic and translatological logistics of the multilingual tourist Internet resource. Multi-authored monograph edited by V.A. Mityagina. Volgograd, 2016, pp. 9-24. (in Russian).

[2] E.Yu. Novikova, "Linguo-pragmatic features of the medical tourism Internet discourse," Journal of the Volgograd State University. Linguistics, vol. 15, is. 3, pp. 78-86, 2016.

[3] A.A. Gureeva, "Travel Internet resource about a city (Volgograd)", "The Homo Loquens Journal, Volgograd, vol. 9, pp. 22-31, 2016.

[4] S.A. Korolkova, A.P. Naumova, "Translation of a travel-guide: difficulties in cultural transfer," Linguistic and translatological logistics of the multilingual tourist Internet resource. Multi-authored monograph edited by V.A. Mityagina”. Volgograd, 2016, pp. 104-130. (in Russian).
[5] V.A. Mityagina, "Communicative actions in the tourist discourse," The Foreign Languages in Higher Education Journal, vol. 4, pp. 88-97, 2009. (in Russian).

[6] I.D. Romadina, "Globalization of content of the international tourism website as a target of translation (English-language websites case study)," Philological Sciences Journal: Theory and Practice, Tambov, is. 9(63), vol. 1, pp. 154-159, 2016.

[7] E.Yu. Novikova, "Communicative and pragmatic paradigm of translation in intercultural travel discourse," Linguistic and translatological logistics of the multilingual tourist Internet resource. Multi-authored monograph edited by V.A. Mityagina. Volgograd, 2016, pp. 153-173. (in Russian).

[8] N.V. Filatova, "Discourse of tourist sphere in pragmatic and linguistic aspects". PhD Thesis, Moscow, 2014. (in Russian).

[9] G. Dann, The language of tourism: a sociolinguistic perspective. UK: CAB International, 1996.

[10] M. Rázusová, The language of tourism. [Electronic resource], Access mode: http://www.pulib.sk/elpub2/FF/Ferencik2/pdf_doc/27.pdf.

[11] E.M. Bruner, Culture on tour: ethnographies of travel. Chicago: University of Chicago Press, 2005.

[12] T. Edensor, "Performing tourism, staging tourism: (Re)producing tourist space and practice," Tourist Studies, 1 (1), pp. 59-81, 2001.

[13] A.A. Gureeva, "Branding PR-function in travel discourse texts: ways to perform", Proc. $3^{\text {rd }}$ All-Russian Scientific Conference "Branding as a communicative technology of the $21^{\text {st }}$ century", S. Petersburg, 2017, pp. 128-131. (in Russian).

[14] T.Yu. Makhortova, "Linguistic aspects of touristic branding's study," Proc. $3^{\text {rd }}$ All-Russian Scientific Conference "Branding as a communicative technology of the 21st century," S. Petersburg, 2017, pp. 141-144. (in Russian).

[15] A. Jansson, "A sense of tourism: new media and the dialectic of encapsulation / decapsulation. Tourist studies sage publications. Los Angeles, London, New Delhi and Singapore. vol. 7(1), pp. 5-24, 2007.

[16] P. Kotler, D. Gertner, "Country as brand, product, and beyond: a place marketing and brand management perspective," Journal of Brand Mangement. Vol. 9 (4-5), pp. 249-261, 2002.

[17] R. Herstein, "Thin line between country, city, and region branding". Journal of Vacation Marketing, 18(2), pp. 147-155. [Electronic resource], Access mode: http://citeseerx.ist.psu.edu/viewdoc/download?doi=10.1.1.841.8718\&rep $=$ rep1\&type $=$ pdf.

[18] P. Kotler, S. Jatusripitak, S. Maesincee, The Marketing of Nations. New York: Simon and Schuster Trade, 1997.

[19] F. Gilmore, "A country - can it be repositioned? Spain - the success story of contry branding," Journal of Brand Mangement. 9 (4), pp. 281293, 2001.

[20] S. Daskou, C. Thom, D.K. Boojihawon, "Marketing a city: Glasgow city of architecture and design," Global Business and Economics Review. 6(1), pp. 22-37, 2004.

[21] K.G. Ward, "Front rentiers to rantiers: "Active entrepreneurs", "Structural speculators" and the politics of marketing," Urban studies, vol. 37(7), pp. 1093-1107, 2000.

[22] S. Anholt, The Anholt City Brands Index, $2^{\text {nd }}$ edn. Seattle, WA: Global Market Institute, 2006.

[23] P. Hopper, "Marketing London in a difficult climate," Journal of Vacation Marketing, 9(1), pp. 81-88, 2003.

[24] E.D. Jaffe, I.D. Nebenzahl, National Image and Copmpetitive Advantage: The Theory and Practice of Place Branding, $2^{\text {nd }}$ edn. Copenhagen: Copenhagen Business School Press, 2001.

[25] L. Zhang, Z.S. Xiaobin, "City branding and the Olympic effect: a case study of Beeijing," Cities, vol. 26(5), pp. 245-254, 2009.

[26] M. Kavaratzis, G.J. Ashworth, "Partners in coffeeshops, cannels and commerce: marketing the city of Amsterdam," Cities, vol. 24(10), pp. 16-25, 2006.

[27] M.N. Rantisi, D. Leslie, "Branding the design metropole: the case of Montreal," Canada. Area, vol. 38(4), pp. 364-376, 2006.

[28] Y. Fan, Branding the nation: what is beeing branded. Journal of Vacation Marketing, 12 (1), 5-14. [Electronic resource], Access mode: http://bura.brunel.ac.uk/bitstream/2438/1286/3/BrandingNat.pdf

[29] E.Yu. Novikova, "Tourist image of the «glocal» city: linguistic and pragmatic dimensions," Journal of the Voronezh State University, Linguistics and Intercultural Communication, vol. 1, pp. 53-57, 2015. (in Russian). 
[30] E.V. Beloglazova, "Discoursivity, interdiscoursivity, polydiscoursivity of children's books: monograph" [Diskursnost, interdiskursnost, polidiskursnost literatury dlya detei: monogrfiya]. St. Petersburg, 2010.

[31] T.A. van. Dejk, Language. Knowledge. Communication, Moscow: Progress, 1989. (in Russian).

\section{Sources}

Multilingual tourist Internet portal of Volgograd and the Volgograd region "The Volgograd region - territory for travel" [Mnogojazychny turistichesky internet-portal goroda Volgograda $i$ Volgogradskoy oblasti «Volgogradsky kray - territoriya puteshestviy». [Electronic resource]. Access mode: http://volga-land.volsu.ru. 